\title{
Penilaian Etis Manager Terhadap Konflik Kepentingan Atas Aktivitas Corporate Social Responsibility
}

\author{
INOVA FITRI SIREGAR ${ }^{1}$, DINI ONASIS ${ }^{2}$ \\ ${ }^{1,2}$ Universitas Lancang Kuning \\ Jln. Yos Sudarso Km 08 Rumbai Telp. (0761) 52581 Fax. (0761) 52581 \\ E-mail : siregar_inovafitri@yahoo.com
}

\begin{abstract}
The bigger an organization or company, the large also residents demand of organization or the company.Many institutions business use everything to win over the competition.Hence, expected can managers runs a business qualify in ethics business managerial, whether moral and a norm the community.Organization as a system is also expected to having social responsibility on the community.The idea of social responsibility or known as Corporate Social Responbility (CSR) is getting widely accepted.Group that supports discourse social responsibility of the opinion that the company cannot be separated from individuals who involved in this, namely the owner and employees.But they should not just think of profit $f$, but also must have sensitivity and concern for public. With the csr activity conducted by the company manager, and has budgeted by the a company so create conflicts of interest.The purpose of this research is to analyze how assessment ethical manager to conflict an interest in the activity of their. Research methodology is descriptive statistics and test how big the influence of assessment ethical manager to conflict an interest in the activity of their corporate social responsibility so that it can be seen anything that affects assessment ethical a manager.Sample used is all employers who engaging in activities corporate social responsibility as many as 30 companies located in pematang pudu sub district Mandau.The result that has been achieved are the judgments ethical manager to a conflict of interest has been included in four criteria: from the benefits, justice, fulfilling the right and maintenance, but each company should have alternative how minimize pressure from the public so that not avoid activity CSR
\end{abstract}

Keywords: Manager Ethic, Conflict of Interest and Corporate Social Responsibility

Pada konteks pembangunan saat ini, perusahaan tidak lagi dihadapkan pada tanggungjawab yang berpijak pada aspek keuntungan secara ekonomis semata, yaitu nilai perusahaan yang direfleksikan dalam kondisi keuangan, namun juga harus memperhatikan aspek sosial dan lingkungannya. Perusahaan bukan lagi sekedar kegiatan ekonomi untuk menciptakan profit demi kelangsungan usahanya, melainkan juga bertanggungjawab terhadap aspek sosial dan lingkungannya. Dasar pemikirannya adalah menggantungkan semata-mata pada kesehatan finansial tidak menjamin perusahaan bisa tumbuh secara berkelanjutan (sustainable). Keberlanjutan akan terjamin apabila perusahaan memperhatikan aspek terkait lainnya, yaitu aspek sosial dan lingkungan (Rudito, Budimanta, Prasetijo: 2004).

Ide mengenai Tanggung jawab Sosial atau yang dikenal dengan Corporate Social Responbility (CSR) kini semakin diterima secara luas. Kelompok yang mendukung wacana tanggung jawab sosial berpendapat bahwa perusahaan tidak dapat dipisahkan dari para individu yang terlibat didalamnya, yakni pemilik dan karyawannya. Namun mereka tidak boleh hanya memikirkan keuntungan finansialnya saja, melainkan pula harus memiliki kepekaan dan kepedulian terhadap publik. Dengan adanya aktivitas tanggung jaawab sosial yang dilakukan oleh para manager perusahaan, dan telah dianggarkan oleh pihak perusahaan sehingga menimbulkan konflik kepentingan. Perusahaan bertanggung 
jawab atas pemangku kepentingan yang membuat keputusan untuk kepentingan perusahaan, tanpa mempertimbangkan kepentingan pribadi. Konflik kepentingan dapat timbul apabila penilaian dapat dipengaruhi untuk kepentingan pribadi

Perkembangan CSR tidak bisa terlepas dari konsep pembangunan berkelanjutan (sustainability development), definisi pembangunan berkelanjutan menurut The World Commission On Environment and Development yang lebih dikenal dengan The Brundtland Comission, bahwa pembangunan berkelanjutan adalah pembangunan yang dapat memenuhi kebutuhan manusia saat ini tanpa mengorbankan kemampuan generasi yang akan datang dalam memenuhi kebutuhan mereka (Solihin: 2009).

The Brundtland Comission dibentuk untuk menanggapai keprihatinan yang semakin meningkat dari para pemimpin dunia terutama menyangkut peningkatan kerusakan lingkungan hidup dan sumber daya alam yang semakin cepat. Selain itu komisi ini juga dibentuk untuk mencermati dampak kerusakan lingkungan hidup dan sumber daya alam terhadap ekonomi dan pembangunan sosial. Oleh karenanya, konsep sustainability development dibangun diatas tiga pilar yang berhubungan dan saling mendukung satu dengan lainnya, Ketiga pilar tersebut adalah sosial, ekonomi, dan lingkungan, sebagaimana ditegaskan kembali dalam The United Nation 2005 World Summit Outcome Document (Solihin: 2009).

Hubungan keagenan merupakan suatu kontrak dimana satu atau lebih orang (prinsipal) memerintah orang lain (agen) untuk melakukan suatu jasa atas nama prinsipal serta memberi wewenang kepada agen membuat keputusan yang terbaik bagi prinsipal. Jika kedua belah pihak tersebut mempunyai tujuan yang sama untuk memaksimumkan nilai perusahaan, maka diyakini agen akan bertindak dengan cara yang sesuai dengan kepentingan prinsipal. Masalah keagenan potensial terjadi apabila bagian kepemilikan manajer atas saham perusahaan kurang dari seratus persen (Masdupi, 2005). Dengan proporsi kepemilikan yang hanya sebagian dari perusahaan membuat manajer cenderung bertindak untuk kepentingan pribadi dan bukan untuk memaksimumkan perusahaan. Inilah yang nantinya akan menyebabkan biaya keagenan (agency cost). Jensen dan Meckling (1976) mendefinisikan agency cost sebagai jumlah dari biaya yang dikeluarkan prinsipal untuk melakukan pengawasan terhadap agen. Hampir mustahil bagi perusahaan untuk memiliki zero agency cost dalam rangka menjamin manajer akan mengambil keputusan yang optimal dari pandangan shareholders karena adanya perbedaan kepentingan yang besar diantara mereka.

Etika adalah padangan, keyakinan, dan nilai akan sesuatu yang baik dan buruk, benar dan salah. Etika manajerial merupakan sandar perilaku yang memandu manajer dalam pekerjaan mereka. Ricky W. Griffin dalam bukunya yang berjudul "Business" mengklasifikasikan etika manajerial ke dalam tiga kategori, yaitu: Perilaku terhadap karyawan; Perilaku terhadap organisasi; Perilaku terhadap agen ekonomi

Adapun 3 langkah yang disederhanakan untuk menerapkan penilaian etis terhadap situasi yang dapat timbul selama melakukan aktifitas bisnis : Menggumpulkam informasi aktual yang relevan; Menganalisis fakta-fakta untuk menentukan nilai moral yang paling tepat; Melakukan penilaian etis berdasarkan kebenaran atau kesalahan terhadap aktifitas atau kebijakan yang akan kita nilai tersebut

\section{METODE}

Lokasi penelitian adalah orang atau peristiwa yang sedang diteliti. Adapun yang menjadi objek dalam penelitian ini adalah Perusahaan yang terlibat dalam kegiatan Corporate Social Responsibility yang masuk dalam kelompok gabungan 
pengusaha suku sakai dikecamatan Mandau Kabupaten Bengkalis

Populasi adalah sekelompok orang, kejadian atau segala sesuatu yang mempunyai karakteristik tertentu sedangkan sampel adalah sebagian dari elemen populasi (Indriantoro dan Supomo:2002:15). Menurut Sugiyono (2005) sampel adalah sebagian dari jumlah dan karakteristik yang dimiliki oleh suatu populasi. Populasi dalam penelitian ini adalah seluruh Perusahaan yang terlibat dalam kegiatan Corporate Social Responsibility yang masuk dalam kelompok gabungan pengusaha suku sakai dikecamatan Mandau Kabupaten Bengkalis

Teknik pengambilan sampel dalam penelitian ini adalah metode random sampling. Metode tersebut merupakan pemilihan sampel dimana populasi yang akan dijadikan sampel yang dikehendaki oleh peneliti sesuai dengan tujuan penelitian (Ghazali:2006). Dengan mempertimbangkan arah dan tujuan penelitian, kriteria yang ditetapkan adalah : Perusahaan yang diteliti adalah perusahaan Perusahaan yang terlibat dalam kegiatan Corporate Social Responsibility yang masuk dalam kelompok gabungan pengusaha suku sakai dikecamatan Mandau Kabupaten Bengkalis; Perusahaan yang menyajikan laporan keuangan secara lengkap. Dengan memperhatikan kriteria diatas, dipilih keseluruhan populasi yang diambil berjumlah 30 Perusahaan yang terlibat dalam kegiatan Corporate Social Responsibility yang masuk dalam kelompok gabungan pengusaha suku sakai dikecamatan Mandau Kabupaten Bengkalis sebagai sampel penelitian.

Data yang digunakan dalam penelitian ini adalah data sekunder, yaitu data yang diperoleh dari pihak lain berupa kuesioner. Data yang digunakan dalam penelitian ini berupa kuesioner dari perusahaan yang terlibat dalam kegiatan Corporate Social Responsibility yang masuk dalam kelompok gabungan pengusaha suku sakai dikecamatan Mandau Kabupaten Bengkalis sebagai sampel penelitian.

Analisis data adalah proses penyederhanaan data ke dalam bentuk yang Jurnal Daya Saing (Vol. 4, No. 1 Feb 2018) mudah dibaca dan diinterpretasikan. Dalam mengolah dan menganalisis data digunakan analisis dan pengujian kuantitatif. Analisis kuantitatif menyangkut pengolahan data dengan menggunakan rumus-rumus yang dapat diterapkan untuk menganalisis data. Tujuan dari analisis ini adalah untuk mendapatkan informasi yang relevan yang terkandung dalam data tersebut dan menggunakan hasilnya untuk memecahkan suatu masalah. Metode analisis data yang digunakan dalam penelitian ini adalah metode analisis deskriptif

\section{HASIL}

Terdapat 30 perusahaan yang diperoleh pendapatnya mengenai bagaimana perilaku etis seorang manajer. Penelitian Etis dan Konflik Kepentingan memiliki makna Strategis, yaitu Manfaat : apakah tindakan dapat memberikan manfaat ; Pemenuhan Hak : apakah dengan tindakan yang dilakukan dapat menjamin terpenuhinya hak semua pihak; Keadilan: apakah tindakan yang dilakukan adil untuk semua pihak; Pemeliharaan: apakah tindakan yang dilakukan konsisten dengan pemeliharaan yang dilakukan.

Tabel 1 Hasil Rekapitulasi Penilaian Etis Manajer terhadap Konflik Kepentingan atas Aktivitas Corporate Social Responsibility (CSR)

\begin{tabular}{|c|c|c|c|}
\hline No & Pertanyaan & Ya & Tidak \\
\hline & Perilaku Organisasi & & \\
\hline 1 & $\begin{array}{l}\text { Perusahaan adalah bagian dari } \\
\text { lingkungan sosial masyarakat, oleh } \\
\text { karena itu oleh karena itu semestinya } \\
\text { ikut berpartisipasi } \\
\text { bertanggungjawab }\end{array}$ & $66,67 \%$ & $33,3 \%$ \\
\hline 2 & $\begin{array}{l}\text { Kegiatan bisnis kerap terjadi masalah, } \\
\text { perusahaan seharusnya } \\
\text { bertanggungjawab atas yang terjadi }\end{array}$ & $100 \%$ & $0 \%$ \\
\hline \multirow[t]{2}{*}{3} & $\begin{array}{l}\text { Manajer perusahaan mempunyai } \\
\text { pengetahuan atas tanggungjawab } \\
\text { sosial }\end{array}$ & $30 \%$ & $70 \%$ \\
\hline & Perilaku Karyawan & & \\
\hline 1 & $\begin{array}{l}\text { Perusahaan tidak mempunyai tenaga } \\
\text { ahli dalam bidang sosial dan } \\
\text { kemasyarakatan }\end{array}$ & $100 \%$ & $0 \%$ \\
\hline 2 & $\begin{array}{l}\text { Manajer memberikan insentif kepada } \\
\text { pegawai yang berprestasi }\end{array}$ & $66,67 \%$ & $33,3 \%$ \\
\hline \multirow[t]{2}{*}{3} & $\begin{array}{l}\text { Manajer yang merekrut teman atau } \\
\text { sanak keluarga ketika masih ada orang } \\
\text { yang lebih memenuhi syarat }\end{array}$ & $0 \%$ & $100 \%$ \\
\hline & $\begin{array}{l}\text { Konflik Kepentingan atas Aktivitas } \\
\text { CSR }\end{array}$ & & \\
\hline 1 & Akan banyak terjadi $\quad$ konflik & $50 \%$ & $50 \%$ \\
\hline
\end{tabular}

p.ISSN: 2407-800X e.ISSN: 2541-4356 


\begin{tabular}{|l|l|l|l|}
\hline No & Pertanyaan & Ya & Tidak \\
\hline & $\begin{array}{l}\text { kepentingan dimasyarakat apabila } \\
\text { perusahaan terlibat dalam aktivitas } \\
\text { sosial }\end{array}$ & & \\
\hline 2 & $\begin{array}{l}\text { Perusahaan melakukan aktivitas sosial } \\
\text { karena mengetahui pentingnya CSR }\end{array}$ & $100 \%$ & $0 \%$ \\
\hline 3 & $\begin{array}{l}\text { Perusahaan melakukan aktivitas CSR } \\
\text { untuk meminimalisir tekanan dari } \\
\text { masyarakat }\end{array}$ & $\begin{array}{l}\text { Perusahaan cenderung menghindari } \\
\text { aktivitas sosial 43,3\% }\end{array}$ & $56,6 \%$ \\
\hline 5 & $\begin{array}{l}\text { Perusahaan mengambil inisiatif dalam } \\
\text { aktivitas dan membuat suatu } \\
\text { pengalokasian biaya CSR }\end{array}$ & $50 \%$ \\
\hline
\end{tabular}

Sumber: Data Olahan

Pada tabel diatas dapat disimpulkan bahwa responden menjawab pertanyaan bahwa perusahaan perlu memiliki tanggung jawal sosial dan beranggapan bahwa banyak persoalan di masyarakat muncul sebagai akibat dari kegiatan perusahaan yang dijalankan sebanyak 30 orang atau sebesar $100 \%$.

Kemudian, hasil pertanyaan bagaimana tanggung jawab sosial yang harus dipikul perusahaan tidak perlu terlibat dalam tanggung jawab sosial sebanyak 20 orang atau sebanyak $66,67 \%$, hal ini dikarenakan pada dasarnya perusahaan tidak memiliki ahli-ahli khusus untuk menangani tanggung jawab sosial ini dalam perusahaan.

Kemudian dilanjutkan dengan pertanyaan yang berkaitan dengan apakah perusahaan menghindari adanya aktivitas sosial , dimana responden yang menjawab setuju atas pertanyaan tersebut sebanyak 13 orang $43,3 \%$, hal tersebut terjadadi sedikit tidaknya para manajer mengetahui tanggung jawab sosial yang dilakukan oleh perusahaan terkait dengan penggunaan pendekatan legal atau jalur hukum untuk menghindarkan diri atau menolak tanggung jawab sosial.

Pertanyaan terakhir dimana perusahaan mengambil inisiatif dalam aktivitas dan membuat suatu pengalokasian biaya CSR sebanyak 15 orang menanggapan benar atau $50 \%$, hal ini disimpulkan bahwa tanggung jawab sosial ntemandang adalah bagian dari tanggung jawab untuk memuaskan stctlceholders.

\section{PEMBAHASAN}

Penilaian Etis Manajer (Perilaku Terhadap Organisasi) Terhadap Konflik Kepentingan Atas Aktivitas CSR

Nilai personal dapal digunakan untuk mengukur etika. Lebih lanjut lagi, Griffin (2000) mengenalkan sebuah model untuk menilai etika. Model penilaian etika tersebut memberikan panduan apakah sesuatu tindakan atau kegiatan memenuhi kriteria atau tidak dapat dinilai dari 4 kriteria etika, yaitu dari sisi manfaat (benefits), pemenuhan hak-hak (rights), prinsip keadilan (justice), dari sifat pemeliharaan (caring

Dari hasil rekapitulasi kuesioner yang telah disebarkan atas pertanyaan pentingnya seorang manajer berpartisipasi dalam aktivitas sosial, bagaimana tanggungjawab perusahaan dan dikoordinasikan oleh seorang manajer apabila terjadi suatu masalah dan bagaimana manajer mempunyai pengetahuan mengenai tanggungjawab sosial dapat disimpulkan telah masuk dalam 4 kriteria dilihat dari sisi manfaat, pemenuhan hak, prinsip keadilan dan sifat pemeliharaan,

Penilaian Etis Manajer (Perilaku Terhadap Karyawan) Terhadap Konflik Kepentingan Atas Aktivitas CSR

Konsep CSR yang perpedoman kepada Triple Bottom Line dimana perusahaan harus menyeimbangkan aktivitas lingkungan, sosial dan ekonomi, dimana pada saat ini kebanyakan perusahaan hanya berorientasi pada laba semata, hal ini terjadi mungkin tidak hanya difahami oleh semua manajer, hal ini yang menjadi masalah, keterbatasan pengetahuan, sehingga akan menimbulkan konflik, baik konflik dari masyarakat maupun konflik terhadap internal perusahaan, manajer akan beranggapan bahwa mereka akan mengeluarkan dana aktivitas CSR karena adanya tekanan dari masyarakat, kemudian akan berakhir pada menghindari adanya aktivitas CSR. 
Dari hasil responden, masuk dalam 4 kriteria dilihat dari sisi manfaat, pemenuhan hak, prinsip keadilan dan sifat pemeliharaan, akan tetapi pada pertanyaan perusahaan cenderung menghindari adanya aktivitas CSR sebanyak dari 30 responden hanyak 43,3\% dan perusahaan melakukan aktivitas CSR bertujuan untuk meminimalisir tekanan dari masyarakat sebanyak 16 orang atau $53,3 \%$, hal ini terjadi disebabkan karena kurangnya pemahaman mereka terhadap konsep dari CSR dan bagaimana mengaplikasi sehingga mereka tidak akan berasumsi bahwa masyarakat menjadi penyebab perusahaan harus melakukan aktivitas sosial tersebut. Hal tersebut dibuktikan pada saat observasi dan wawancara pada responden yang terdapat di daerah duri, perusahaan harus mengeluarkan aktivitas CSR dikarenakan adanya tekanan dari masyarakat, contohnya masyarakat meminta pekerjaan dan mengancam beberapa pegawai untuk diminta dalam hal financial. Dengan demikian dengan adanya kejadian tersebut, akan menjadikan seorang manager akan berperilaku tidak etis sehingga akan menimbulkan penghindaraan aktivitas CSR.

\section{SIMPULAN}

Berdasarkan hasil penelitian dengan mengumpulkan data sekunder terkait analisis biaya lingkungan pada perusahaan yang terdaftar diBursa Efek Indonesia dan Kesesuaiannya terhadap Global Reporting Initiative dapat diambil beberapa kesimpulan sebagai berikut : Perusahaan cenderung menghindari adanya aktivitas CSR sebanyak dari 30 responden hanyak $43,3 \%$ dan perusahaan melakukan aktivitas CSR bertujuan untuk meminimalisir tekanan dari masyarakat sebanyak 16 orang atau 53,3\%, hal ini terjadi disebabkan karena kurangnya pemahaman mereka terhadap konsep dari CSR dan bagaimana mengaplikasi sehingga mereka tidak akan berasumsi bahwa masyarakat menjadi penyebab perusahaan harus melakukan aktivitas sosial tersebut. Hal tersebut dibuktikan pada saat observasi dan wawancara pada responden yang terdapat di daerah duri, perusahaan harus mengeluarkan aktivitas CSR dikarenakan adanya tekanan dari masyarakat, contohnya masyarakat meminta pekerjaan dan mengancam beberapa pegawai untuk diminta dalam hal financial. Dengan demikian dengan adanya kejadian tersebut, akan menjadikan seorang manager akan berperilaku tidak etis sehingga akan menimbulkan penghindaraan aktivitas CSR.

\section{DAFTAR RUJUKAN}

Damayanti, Destia Pentiana. 2013. Global Warming" dalam Perspektif Environmental Management Accounting (EMA) Jurnal Ilmiah ESAI Volume 7, No.1

Galuh Widya Sahasrakirana. 2012. Evaluasi Peran Akuntansi Lingkungan Untuk Mendukung Keputusan Manajemen Lingkungan Dalam Mencapai Sustainability Perusahaan (Pt Sahabat Mewah Dan Makmur). Skripsi

Hansen Mowen. 2007. Accounting Managerial 1. Salemba Empat : Jakarta

Ikhsan, Arfan. 2008. Akuntansi Manajemen Lingkungan.Graha ilmu: Yogyakarta

Ikhsan, Arfan. 2008. Akuntansi Lingkungan Dan Pengungkapannya. Graha Ilmu: Yogyakarta

Ikatan Akuntansi Indonesia.2009. Standard Akuntansi Keuangan. Salemba Empat:Jakarta

Lako Andreas. 2017. Green Accounting. Penerbit Erlangga. Jakarta

Lako Andreas, 2017. Paradigma Sustainable Reporting. Jurnal Ekonomi dan Bisnis

p.ISSN: 2407-800X e.ISSN: 2541-4356 
Mehenna Yakhou and Vernon P. Dorweiler. 2004. Environmental Accounting: An EssentialComponent Of Business Strategy. Business Strategy and the Environment Journal

M.R. Mathews. 2009. The Development of Social and Environmental Accounting Research 19952000. Finance and business journal

Riki Martusa.2009. Peranan Environmental Accounting terhadap Global Warming Jurnal Akuntansi Vol.1 No.2.

Susiana, Nengah, Devi. 2011. Penerapan Akuntansi Lingkungan Untuk Mengoptimalkan Tanggung Jawab Industri Gula (Studi Pada PT Perkebunan Nusantara $X$ Unit Pabrik Gula Lestari Nganjuk). Jurnal Ekonomi dan Bisnis 